\title{
Economic Impact Of Railroad Line Abandonment On Regional And Urban Areas: A Case Study
}

Duane J. Rosa, West Texas A\&M University, USA

\begin{abstract}
This case study focuses on the economic and legal issues affecting a region or community as a result of potential railroad line abandonment. Railroad line abandonment, where rail service is being discontinued over a rail line or segment of a line, is becoming an increasing common practice in the United States. The loss to an affected community or a region can have significant economic and social consequences, especially when the rail line to be abandoned represents one of the principal modes of transportation into and out of the affected area. This can limit future growth and the marketing of an area to potential entrants. This case study analyzes the specific steps required by the railroad and interested parties in the rail line abandonment process as well as alternative arrangements to abandonment. It concludes by analyzing the economic issues related to alternative uses of railroad right-of-way, including its use as a rail trail. This case study offers students the opportunity to analyze the various economic and legal issues involved and develop alternative plans from both the perspective of the railroad as well as the affected community or region.
\end{abstract}

Keywords: Railroad Line Abandonment; Economic and Legal Impact; Railroad Line Planning

\section{INTRODUCTION}

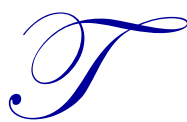

he railroad system in the United States matured during the late 1800's with railroad mileage reaching a peak in the early 1900's at about 254,000 miles. It is now down to less than 140,000 miles (Bureau of the Census, 2012). Railroads initially grew in response to the rapid growth and expansion of the United States, especially in the industrial regions in the Northeast. This was followed by expansion of the agrarian regions in the South and Midwest and the westward expansion of the country. Today, however, due to competing modes of transportation and other economic and financial issues, abandoned railways have become a prevalent fact in many areas of the country. Railroad line abandonment means that rail service or traffic over a particular segment of a rail line is being discontinued. Typically, discontinuation of rail service occurs when a rail line is not profitable resulting from declining shipments and revenue sources for the railroad. It can also be discontinued because an entire area is generating insufficient rail traffic to justify continuation of service. This case study focuses on the economic and financial issues involved in railroad line abandonment and an analysis of options that a community or region can use as a result.

Railroad line abandonment can greatly affect areas of the country which lose rail service and the loss to the affected community or a region can have significant economic and social consequences. This is especially the case when the rail line to be abandoned represents one of the principal modes of transportation into and out of an area. This can greatly limit the future growth and direction of a community by hindering economic expansion and development opportunities. This includes the ability to attract certain types of industries which depend on rail service. Quality of life within a community may also deteriorate as pollution levels and roadway degradation increase with increased truck traffic as the alternative means of transportation. The negative impacts on a community facing railroad line abandonment may include: 


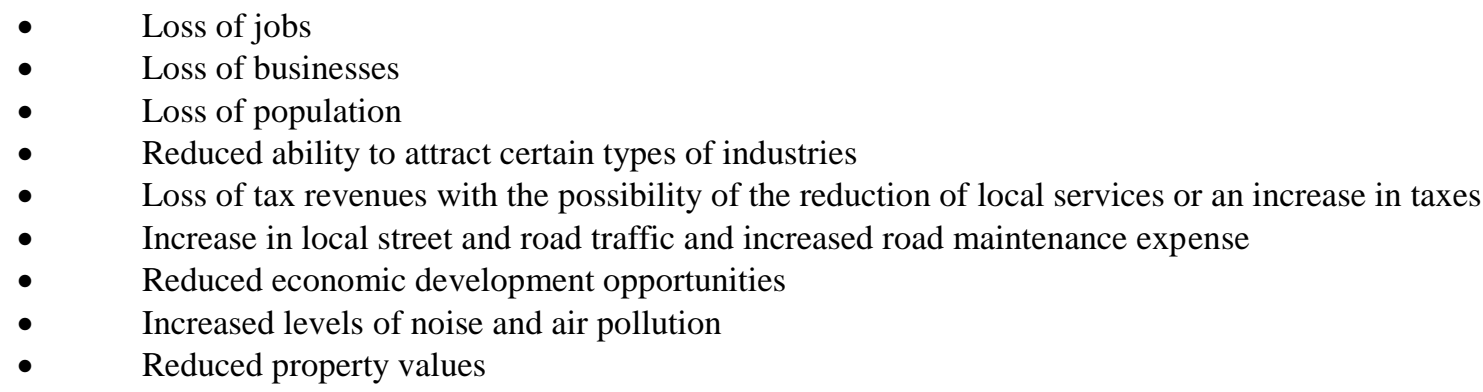

Businesses are especially vulnerable to negative impacts associated with the loss of rail services to an area. To them, the loss of rail service may become a question of survival. The amount of rail dependence on rail service will dictate the overall effects on a specific business, but any business may experience secondary impacts regardless of their reliance on rail service.

Firms using rail service to any extent have three choices resulting from line abandonment: 1) use trucks for all freight requirements, 2) relocate to an area where rail service is available, or 3) possibly go out of business. Those firms able to shift all of their transportation needs to trucks may experience an increase in freight rates, reduction in revenues, and loss of market. Reduction may also occur in employment opportunities and in the profitability of the business. In addition, firms may become captive to one remaining transportation mode and lose their negotiating position as a business. The potential business impacts resulting from the abandonment of light density lines are shown in Figure 1 (Rosa, 1998). In a survey done by the United States General Accounting Office (GAO, 1987), it was found that, on average, the shipping and related costs to a firm having lost rail service due to abandonment increased ten percent. In addition, almost 41 percent of the firms reported a loss of market and 13 percent of the firms indicated that they found it necessary to relocate their business as a direct result of the abandonment.

States also have legitimate concern about the potential loss of rail service to different areas. These concerns are both economic and social in character and encompass the following areas:

- Economic Development: Without a balanced freight transportation system, economic development objectives of the state may be difficult to achieve.

- $\quad$ Regional Development: Certain regions of the state will undoubtedly be at a distinct disadvantage in their efforts to grow and remain economically viable.

- $\quad$ Competitive Position: The state may find that their competitive position as it relates to other states is diminished.

- $\quad$ Quality of Life: Certain quality of life considerations are lost or diminished when an area loses rail freight service. While these may be difficult to quantify, they are no less valid and need to be recognized when confronting possible rail line abandonment. 


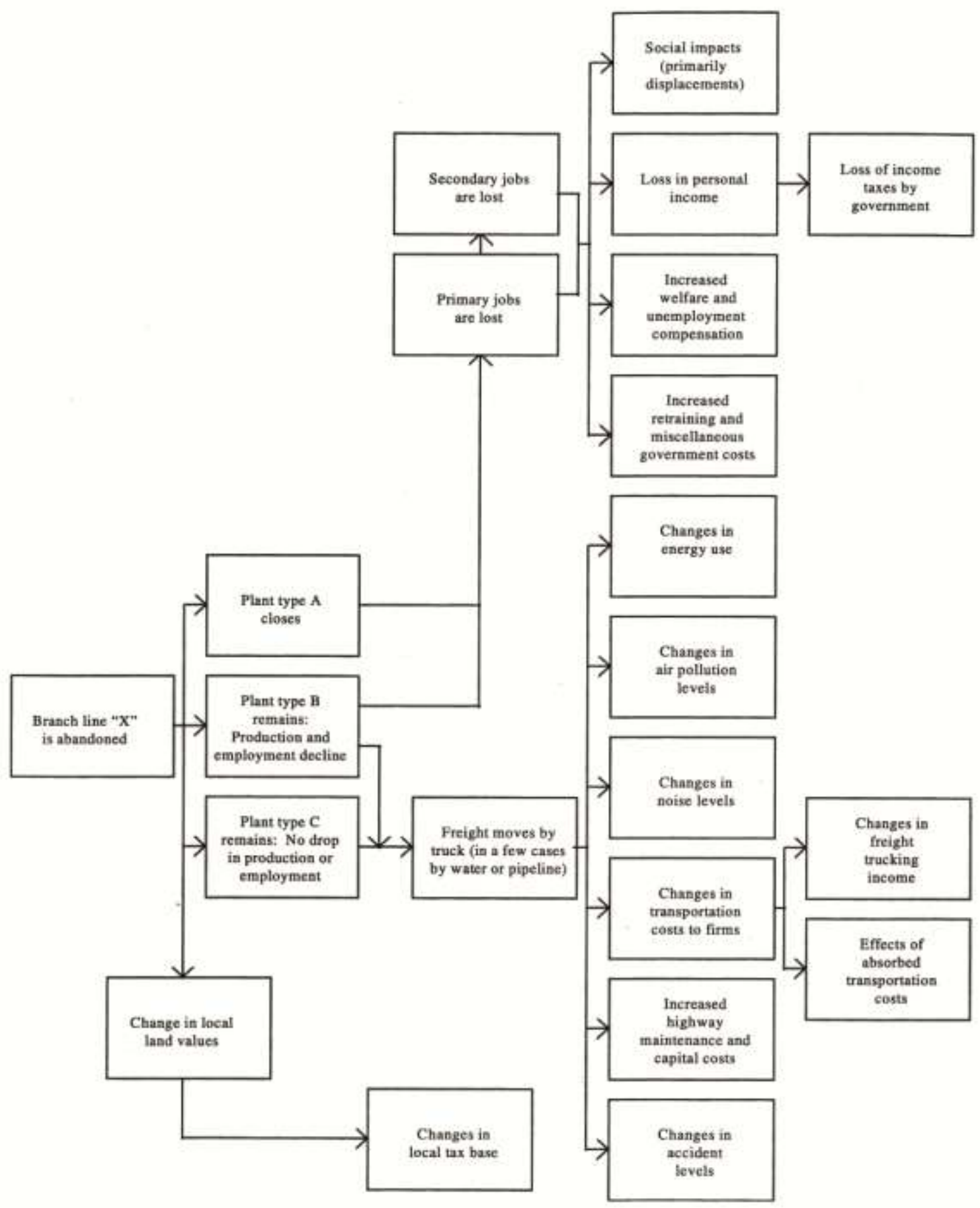

Figure 1: Potential Impacts Resulting from the Abandonment of Light Density Lines

\section{SURFACE TRANSPORTATION BOARD}

In 1995, the U.S. Congress enacted the ICC Termination Act, which abolished the Interstate Commerce Commission and established the Surface Transportation Board (STB) to resolve railroad rate and service disputes and has jurisdiction over rail abandonments (Interstate Commerce Commission, 1995). According to the Act, a railroad may abandon a line only with the STB's permission. Under a detailed abandonment application process for 
active lines, STB balances the economic burden of continued operation against the public's need for the service. Permission is usually given to abandon line on which there are significant operating losses. But, the carrier's ability to earn more money by disinvesting itself from a line and reinvesting its assets elsewhere is not sufficient to allow abandonment in the face of a strong public need for service.

A rail carrier may take advantage of certain exemptions to the abandonment process. Lines over which no local traffic has moved for two years without any formal complaint have been exempted from traditional regulatory scrutiny. This type of abandonment is still subject to analysis by the Surface Transportation Board regarding the impact it could have on regional and local labor effects and environmental conditions.

\section{RAIL LINE ABANDONMENT AND APPEAL PROCESS}

In any abandonment case, the Surface Transportation Board must determine whether the "present or future public convenience and necessity require or permit" the abandonment. In making this determination, the STB must balance two competing factors. The first is the need of local communities and shippers for continued service. That need must be balanced against the broader public interest in freeing railroads from potential financial burdens that drain their overall financial health and lesson their ability to operate economically elsewhere. The railroad must show how continued operation of the line would be a burden to it. If the railroad does demonstrate this burden, then evidence of the public's need for continued service, along with environmental impacts, is examined. If so, parties opposing abandonment must present information on the effect on local businesses, surrounding communities, the local economy, and the environment, as well as challenging the railroad's financial data.

Once an application for abandonment has been filed by the railroad, along with them publishing a diagram map or narrative in a newspaper in each county containing the rail line, parties have 45 days to submit protests (U.S. Code of Federal Regulations, 2011). They can address the impact abandonment would have on an area by computing, (1) markets that would be lost without rail service, (2) the number of business failures or relocations and lost jobs that would result from abandonment, and (3) the number of current or future ventures that depend upon continued rail service. Local shippers can also present testimony concerning past and future use of the rail line and the potential impact on their business of rail line abandonment.

Besides the economic impact of the proposed abandonment, the opposing parties could point out any effect the abandonment would have on the environment. This is a very important aspect for many urban and congested areas. The increased use of alternative modes of transportation, such as trucks, could adversely affect air quality in the region as well as noise and congestion levels. The environmental consequences of the abandonment are assessed by the STB's Section of Energy and Environment (SEE).

In order for opposing parties to be successful in stopping the railroad abandonment process, they need to not only show the potential harm they will suffer from the from abandonment, but also attempt to discredit the railroad's evidence of losses or burden from operating the line. This should include an evaluation of the railroad's financial data. The railroad will attempt to show that (1) it is not receiving, and cannot reasonably expect in the future, to earn sufficient revenues from the line and/or (2) it expects to face significant costs on the line in the future that it will not be able to recover. Normally, the past revenue generated by the railroad can be determined fairly accurately based on carrier and shipper records. Other data are subject to interpretation by both parties. These include:

- $\quad$ projecting the revenues for the railroad line

- $\quad$ isolating the historical expenses of operating and maintaining the line and projecting future operating maintenance, and rehabilitation expenses

- $\quad$ calculating the opportunity costs of operating the rail line

Railroads are required to include in their abandonment application projections of their revenues and costs on the line for a forecast year, the 12-month period beginning the first day of the month in which the application is filed. To project future revenues and costs, the railroad must necessarily make assumptions. Opposing parties should critically evaluate those assumptions. It is impossible for the railroad to predict the future with certainty and, in 
many cases, the opposing parties may be in as good or better position than the railroad to make accurate predictions. For example, a substantial component of revenues usually consists of the number of shipments originating or terminating on the line. Shippers on the line, knowing their own shipping and transportation needs, may be able to dispute the railroad's projections of future traffic.

\section{ALTERNATIVES TO ABANDONMENT}

When railroads are first considering railroad line abandonment, users and interested parties should consider alternatives to abandonment. The fact that the existing railroad believes the line is no longer economically viable does not mean the line cannot continue under other arrangements. The U.S. Congress and the Surface Transportation Board have made it easier to preserve rail service by acquiring or subsidizing rail lines. They have adopted procedures that make it possible to force the sale or subsidy of lines slated for abandonment when the parties cannot agree on the price or terms of the subsidy. This is to encourage continued service for (1) lines approved for abandonment and (2) lines potentially subject to abandonment.

As soon as the Notice of Intent to abandon is filed by the railroad, interested parties may request data on subsidy and acquisition costs. This includes an estimate of the minimum price or annual subsidy needed to keep the line in operation, reports on the physical condition of the rail line, and traffic and other data necessary to determine the amount of annual financial assistance needed to continue service. With this data, interested parties can start to develop a thorough feasibility study. Often, the state will assist the railroad by providing substantial money for rehabilitation of the line.

Procedures are available for those who would like to purchase a rail line and assume the common carrier obligation to provide service (contract or non-contract) over the line, or who would like to offer the carrier a subsidy to continue to provide the service. This is called an Offer of Financial Assistance (OFA). Each OFA is reviewed by the Surface Transportation Board to determine whether the interested party is financially responsible and whether the offer is reasonable. A copy of the annual report or other financial statements must be submitted with the offer to show its financial responsibility. If the offer is a subsidy, it should cover the railroad's avoidable operating losses on the cost of the line, the net liquidation, or going concern value of the line.

If the Surface Transportation Board finds that the offer is reasonable, it will postpone the abandonment and give the parties an opportunity to negotiate. If those negotiations are successful and the parties voluntarily enter into a purchase (or subsidy) agreement which will result in continued rail service, the STB will approve the transaction and dismiss the abandonment application.

Should the parties fail to agree on the amounts or terms of the subsidy or purchase, either party may ask the STB to establish terms and conditions. The Surface Transportation Board must issue decision-setting terms and conditions within 30 days after the request is made. If the interested party chooses to accept them, the railroad, by law, is forced to comply. When the railroad receives more than one OFA, it can decide which offer is in the best interest of the railroad. If the STB established terms and conditions and the party subsequently withdraw its offer, other qualified parties may take its place, forcing the railroad to go through with the subsidy or sale under those terms and conditions.

\section{FEEDER DEVELOPMENT PROGRAM}

The Feeder Development Program was designed as an alternative to abandonment. Congress envisioned it as a method of allowing shippers, communities, or other interested parties to acquire rail lines before an abandonment application is filed by the railroad protests (U.S. Code of Federal Regulations, 2011). If a rail line has been listed on a carrier's system diagram map as potentially subject to abandonment, a financially responsible party can compel the Surface Transportation Board to require a railroad to sell the line. The price for this type of sale is either agreed to by the parties or set by the STB.

The sales proceeding commences upon filing of a feeder line application with the STB. The applicant must show that it can (1) pay the net liquidation value of the rail line or its going concern value, whichever is higher, and 
(2) provide adequate service for at least three years. The STB has 15 days to reject the application if it does not contain the prescribed information or accept it by filing a notice in the Federal Register no later than 30 days after the application is filed. Within 30 days after the application is accepted, any other interested party may file a competing application to acquire all or any part of the same line. At the same time, the railroad may submit verified statements containing their evidence and arguments. The STB must publish its decision on the sale in the Federal Register. If two or more parties accept the STB's terms, the owning railroad has 15 days to decide which party's offer it wishes to accept.

\section{ALTERNATIVE USES FOR RAILROAD RIGHTS-OF-WAY}

A very important option for communities facing potential rail line abandonment is to negotiate other public use for the railroad right-of-way. The ICC Termination Act and the National Rails to Trails Act, along with STB regulations, give interested parties the opportunity to negotiate voluntary agreements to use a railroad right-of-way that otherwise would be abandoned for recreational or other public use, such as a commuter rail service or a highway. These methods of preserving a railroad corridor are known as "rail banking," meaning that the right-ofway is preserved for future use as a railroad. Many railroads do not own the land on which their tracks lie. Rather, they have easements over the land of adjoining property owners. Unless those easements are "rail-banked" by converting them to a trail or other public use, they are eliminated (Huffington Post, 2013; North Carolina Rail Trails, 2013).

Rail banking is a voluntary agreement between the rail line proposing to abandon a right-of-way and a party interested in converting it to a trail (trail sponsor). During the abandonment process, a party (trail sponsor) can submit a request to the Surface Transportation Board to use right-of-way for a trail. In this request, the trail sponsor must agree that (1) the use of the right-of-way could be subject to restoration of rail service in the future and (2) it will assume all managerial, financial (including payment of property taxes), and legal responsibility for the right-ofway, including any liability arising out of its use as a trail. If the STB determines that the right-of-way can be abandoned and if the rail line agrees to negotiate, the Board will issue trail use authority to the trail sponsor to allow the parties to negotiate a final trail use agreement. If a rail-banking agreement is reached between the parties, it may be implemented without any analysis or approval by the Board. Also, approval of the trail use agreement is not required from the landowners that may have underlying rights to the property or the local community. Since railbanked properties are not considered to be abandoned under the law the rights-of-way remain intact. There have been several recent cases related to public ownership claims of right-of-way and use as rail trails (Snyder, 2013).

\section{RIGHT-OF-WAY SUITABILITY ANALYSIS}

A study period provided by the Surface Transportation Board allows interested parties to evaluate potential uses of abandoned railroad right-of-way. This suitability analysis includes the following steps: (1) list possible uses, (2) inventory suitability characteristics, and (3) suitability assessment. The first step in suitability analysis is to identify the uses to which an abandoned right-of-way might be put to use. These uses include recreation, transportation, conservation/open space, and utility. Table 1 shows a list of possible uses.

Table 1: Possible Uses for Abandoned Right-of-Way

\begin{tabular}{|l|c|c|c|}
\hline \multicolumn{1}{|c|}{ Recreation } & Transportation & Conservation & Utility Uses \\
\hline Special use trails & Freeways & Wilderness Preserve & Electric power transmission lines \\
\hline Hiking/Jogging trails & Arterial streets & Protected Areas & Electric distribution lines \\
\hline Backpacking trails & Scenic parkways & & Above ground communication lines \\
\hline Bicycle trails & Local streets & & Buried communication lines \\
\hline Bikeway(transportation) & Scenic roads & & Oil and gas pipelines \\
\hline Equestrian trails & Fixed rail & & Water and sewer pipelines \\
\hline Excursion trails & Bikeway (transportation) & & \\
\hline
\end{tabular}

The second step is to obtain data on the characteristics of each line that make it suitable for particular uses. Among the important characteristics which determine whether a particular right-of-way will be suitable for a given use include how title is held to the right-of-way, the presence and condition of any bridges, whether railroad track is 
still in place, the length and width of the right-of-way, the general topography of the area (e.g. plains, hills, mountains), adjoining land uses, and accessibility of the right-of-way to the public. Following this step, a suitability assessment should be undertaken evaluating issues such as financial viability, environmental impacts, health and safety, and any socioeconomic concerns. The purpose of this final step is to assure interested parties that a multicriteria analysis has been done on the right-of-way in question. The analysis can then be used to develop an economically and socially viable use for the abandoned right-of-way.

\section{CONCLUSION}

This case study discusses the many, and sometimes conflicting, issues that communities and regions face with potential rail line abandonment. All options need to be carefully evaluated from continued use of the rail line for freight by the railroad or a third party to alternatives uses for the abandoned right-of-way. The case study gives students the opportunity to evaluate these opportunities from different planning perspectives, analyzing the legal and economic issues involved.

\section{AUTHOR INFORMATION}

Dr. Duane J. Rosa is a Professor of Economics and Regional Director of the Texas Transportation Institute at West Texas A\&M University. He has been with the university since 1984. Dr. Rosa holds a Ph.D. in economics from Texas Tech University and Master's degrees in civil engineering and economics. He was a Fulbright Professor at the University of Iceland in 1992 and 1993. He teaches courses in managerial economics, environmental economics, and microeconomic theory. His research interests include transportation, energy, and water resources. He has published articles in the Journal of Business Case Studies, International Business and Economics Research Journal, and the Journal of Business and Economics Research.

\section{REFERENCES}

1. $\quad$ Bureau of the Census (2011). Statistical abstract of the United States: 2012. Tables 1064, 1068.

2. Huffington Post (2013, September 21). All Aboard! Abandoned railroad tracks gain new life as green trails. Retrieved from http://www.huffingtonpost.com/adrian-benepe/all-aboard_b_3786764.html

3. Interstate Commerce Commission (1995). ICC Termination Act. Public Law 104-88, $104^{\text {th }}$ U.S. Congress, Page 109, Stat. 803.

4. North Carolina Rail Trails (2013). Retrieved from http://www.ncrailtrails.org/web/

5. Rosa, D., Roop, S., Warner, J., \& Dickinson, R. (1998, November). The railroad system of Texas: A component of the state and national transportation infrastructure. Texas Department of Transportation (TxDOT), Report FHWA/TX-99/1703-3.

6. Snyder, T. (October 24, 2013). Supreme Court to consider fate of rail trails. Retrieved from http://dc.streetsblog.org/2013/10/24/supreme-court-to-consider-fate-of-rail-trails/

7. U.S. Code of Federal Regulations (2011). Title 49 - Transportation, Chapter X - Surface Transportation Board, Parts 1152.20- 1152.29.

8. U.S. General Accounting Office (1987). Abandonment Activity and Shipper Views on Rail Service. Washington, D.C., July 1987. 


\section{NOTES}

